\title{
EGFR Analysis in Cytologic Samples of Lung Adenocarcinoma by Microdissection
}

\author{
Jeong Yeon Han $^{1}$, Hoon Taek Lee ${ }^{3}$, and Seo Young $\mathrm{Oh}^{2,3}$ \\ ${ }^{1}$ Department of Pathology, Seoul National University Hospital, Seoul 03080, Korea \\ ${ }^{2}$ Department of Pathology, Konkuk University Medical Center, Seoul 05030, Korea \\ ${ }^{3}$ Department of Animal Biotechnology, College of Animal Bioscience \& Technology, Konkuk University, Seoul 05029, Korea
}

\section{미세 절제에 의한 폐 선암 세포 검체에서 $\mathrm{EGFR}$ 분석}

\author{
한정연 ${ }^{1}$, 이훈택 ${ }^{3}$, 오서영 2,3 \\ ${ }^{1}$ 서울대학교병원 병리과, ${ }^{2}$ 건국대학교병원 병리과, ${ }^{3}$ 건국대학교 동물생명공학과
}

\begin{abstract}
The discovery of activating mutations in EGFR in a subset of lung adenocarcinomas was a major advance in our understanding of lung adenocarcinoma biology, and has led to groundbreaking studies that have demonstrated the efficacy of tyrosine kinase inhibitor therapy. Cytologic specimen procedures have become increasingly popular for obtaining diagnostic material in lung carcinomas. However, frequently the small amount of material or sparseness of tumor cells obtained from cytologic preparations limit the number of specialized studies, such as mutation analysis, that can be performed. In this study we used microdissection to isolate small numbers of tumor cells to assess for EGFR mutations from 76 cytological smear slides of patients with lung adenocarcinomas. We compared our results with previous molecular assays that had been performed on either surgical or cytology specimens as part of the patient's initial clinical work-up. Not only were we able to detect the identical EGFR mutation through the pyrosequencing, but we were also able to consistently detect the mutation from as few as 25 microdissected tumor cells. Furthermore, isolating a purer population of tumor cells resulted in increased sensitivity of mutation detection as we were able to detect mutations from microdissection-enriched cases. Therefore, microdissection can not only significantly increase the number of lung adenocarcinoma patients that can be screened for EGFR mutations, but can also facilitate the use of cytologic samples in the newly emerging field of molecular-based personalized therapies.
\end{abstract}

Keywords: Cytologic specimens, Microdissection, EGFR mutation, Lung adenocarcinomas

This is an Open Access article distributed under the terms of the Creative Commons Attribution Non-Commercial License (http://creativecommons.org/licenses/by-nc/4.0) which permits unrestricted non-commercial use, distribution, and reproduction in any medium, provided the original work is properly cited.

Copyright () 2015 The Korean Society for Clinical Laboratory Science. All rights reserved.
Corresponding author: Seo Young Oh Department of Pathology, Konkuk University Medical Center, Seoul 05030, Korea Tel: 82-2-2030-5631 E-mail: syoh@kuh.ac.kr

Received: June 9, 2015 Revised $1^{\text {st: June } 25,2015}$ Revised 2 ${ }^{\text {nd: }}$ July 6, 2015 Accepted: July 7, 2015

\section{Introduction}

The emergence of targeted therapeutics in lung adenocarcinoma has revolutionized the field of personalized medicine and established a prognostic and predictive role for molecular analysis in conjunction with morphologic diagnosis in determining clinical outcomes of patients with advanced-stage disease (Eberhard et al., 2005; Jackman et al., 2009; West et al., 2009). The epidermal growth factor receptor $(E G F R)$ is known to play a role in the development and progression of cancer, and somatic mutations within the tyrosine kinase domain of EGFR have been identified in a subset of lung adenocarcinomas. What has made targeted therapy an exciting and developing field is that several 
clinical trials using tyrosine kinase inhibitors, gefitinib and erlotinib, have shown that patients with advanced lung adenocarcinomas harboring an EGFR mutation have a longer progression-free survival and response to tyrosine kinase inhibitors as a first-line therapy, whereas patients without these mutations have better outcomes with chemotherapy (Pao et al., 2004; Lynch et al., 2004; Paez et al., 2004; Han et al., 2005; Rosell et al., 2006; Mok et al., 2009; Jackman et al., 2009). Cytology specimens are often underutilized for decisions regarding targeted cancer therapy (Clark, 2009). Mutation analysis of cytology cell block material shows similar or higher sensitivity in comparison with surgical specimens and was likely dependent on the proportion of tumor cells present in a given specimen (Smouse et al., 2009). Molecular analytical techniques have rapidly gained pace in recent years and high-throughput methods have changed the study of molecular events associated with pathological processes (Asano et al., 2006; Janne et al., 2006; Smith et al., 2008) However, molecular diagnosis is limited by the amount of tissue available for analysis and the number of tumor cells present within the sample. Tumor cell heterogeneity presents a challenge for molecular assays, where it is often necessary to isolate subpopulations of cells within a neoplasm to obtain a pure sample of tumor cells for DNA isolation and amplification. Microdissection provides a simple technique for rapid and accurate selection of pure populations of cells under direct microscopic visualization (Emmert-Buck et al., 1996; Fend and Raffeld, 2000; Harrell et al., 2008; El-Serag et al, 2009).

In this study, we assessed the feasibility of using microdissection to enable and facilitate EGFR mutation detection from cytological samples and compared the performance of this technique with results from standard mutational assays that had been previously performed on surgical or cytology materials as part of the routine clinical work-up.

\section{Materials and Methods}

\section{Clinical samples}

A total of 76 cytology specimens of lung adenocarcinomas from 76 patients were examined, including 37 bronchial washing and 39 pleural fluids. All cases had cytomorphological evaluation of direct smears and/or cytospins and were confirmed by cytopathologist the diagnosis. All clinical specimen collected from the patient in the Department of Pathology files of Konkuk University Medical Center were used. Study approval was obtained from the Institutional Review Board (KUH 1210029). All specimens also had 95\% ethanol fixed. The fixed cells were stained using the Papanicolaou procedure. All specimens were analyzed for EGFR mutations.

\section{Microdissection of tumor cells on archival cytology smear slide specimens}

The tumor cells were aspirated from the lung under were smeared on glass slides and fixed with 95\% ethanol. The fixed cells were stained using the Papanicolaou procedure. After the tumor cells were marked by the cytopathologist, the cover slides were removed in xylene and air dried.

For high quality cell morphology resolution, tumor cells on the slides were treated by resolution solution for $5 \sim 10$ seconds. The tumor cells were dissected with a 26 gauge needle under $100 \times$ magnification using a square micrometer in the microscope. A needle tip was carefully submerged in a tube containing $100 \mu \mathrm{l}$ of each DNA extraction solution to collect the cells (Oh and Lee, 2015). All collected lung adenocarcinoma cells were performed EGFR mutation analysis. Tumor cells were dissected 300, 200, 100, 50 and 25 cells from archival smear slide specimens of 76 cytology cases.

\section{DNA extraction}

Briefly, $100 \mu \mathrm{l}$ of ammonium sulfate DNA extraction buffer solution $\left(16 \mathrm{mM}\left(\mathrm{NH}_{4}\right)_{2} \mathrm{SO}_{4}, 50 \mathrm{mM}\right.$ Tris- $\mathrm{HCl} \mathrm{pH} 8.5,1 \mathrm{mM}$ EDTA pH 8.0, and 0.5\% Tween-20) was added to the dissected cells in a $0.2 \mathrm{ml} \mathrm{PCR}$ tube, and Proteinase K (Takara Bio. Inc., Shiga, Japan) was added to a final concentration of $200 \mu \mathrm{g} / \mathrm{ml}$, and then digested at $56^{\circ} \mathrm{C}$ for 1 hour. Following the incubation, the PCR tube was heated to $100^{\circ} \mathrm{C}$ for 10 minutes in a dry bath incubator (Major science, New Taipei City, Taiwan) with 10\% Chelex-100 (Bio-Rad, CA, USA). After gentle shaking and centrifuged at $13,000 \mathrm{Xg}$ for 10 minutes to elute the DNA (Oh et al., 2014). 


\section{EGFR mutation analysis using pyrosequencing}

Microdissection in lung adenocarcinoma cells were used for this analysis. Biotinylated (B) PCR primer sequences for the amplification of EGFR mutation sites were as follows: exon 18, 5'-Biotin-GCTCCCAACCAAGCTCTCTT-3'(F) and 5'-TATACACCGTGCCGAACGC-3'(R); exon 19, 5'-GCATGTGGCACCATCTCA-3'(F) and 5'- Biotin -AAAAGGTGGGCCTGAGGTT-3'(R); exon 20, 5'- Biotin -ATGGCCAGCGTGGACAAC-3'(F) and 5'-TTTGTGTTCCCGGACATAGTC-3'(R); exon 21, 5'- ACCGCAGCATGTCAAGATCAC-3'(F) and 5'-BiotinTCCGCACCCAGCAGTTTG- 3 '(R). Three microliters of DNA was added to a total $50 \mu \mathrm{lPCR}$ solution mixture containing 0.2 $\mathrm{mM}$ of each dNTP, $1.5 \mathrm{mM} \mathrm{MgCl}_{2}, 1 \times$ Immolase buffer, $1.5 \mathrm{U}$ of Immolase DNA Taq polymerase, and 20 pmol of each primer. PCR was carried out with an initial denaturation for 5 minutes at $95^{\circ} \mathrm{C}$ followed by 40 cycles of 30 seconds at $95^{\circ} \mathrm{C}$, 30 seconds at $54^{\circ} \mathrm{C}$ (exons 18,21 ), $60^{\circ} \mathrm{C}$ (exon 19) or $55^{\circ} \mathrm{C}$ (exon 20), 30 seconds at $72^{\circ} \mathrm{C}$ and incubation for 10 minute at $72^{\circ} \mathrm{C}$. PCR products were resolved by agarose gel electrophoresis to confirm successful amplification. The biotinylated products were then immobilized to streptavidin-coated beads using the solution from a commercial PSQTM96 Sample Preparation kit. Three microliters of beads were diluted in binding buffer with $15 \mu$ of biotinylated PCR products and incubated for 10 minutes at room temperature. The beads were then transferred to a filter probe, and liquid was removed by vacuum filtration. The DNA in the denaturation solution was separated, templates were washed with washing buffer, transferred to a PSQ 96 SNP plate and annealed with the following sequencing primers: exon 18 E709K, 5'TGATCTTTTTGAATTCAGTT-3' and G719A and G719S 5'-CCGAACGCACCGGAG-3'; exon 19 deletion, 5'-ATTCCCGTCGCTATC-3'; exon 20 T790M, 5'-GATGCCCAGCAGGCG-3'; and exon 21 L858R and A859T, 5'-AAGATCACAGATTTTGG-3' in annealing buffer at room temperature. Finally, the specimens were analyzed using a PyroMark ID System with a SNP reagent kit for sequencing (Hwang, 2009; Kim et al., 2013). The EGFR mutation analysis was performed with three specimens from each cell number group.

\section{Results}

\section{The minimal number of cells required for EGFR mutational analyses}

To assess the minimal number of cells required to successfully run mutation analysis, we were dissected 300, 200, 100, 50 and 25 cells tumor cells from archival smear slide specimens of 76 cytology cases. It was analyzed by the pyrosequencing. The mutations were consistently detected in all the samples tested, including samples contain ing only 25 cells by the pyrosequencing (Table 1). EGFR mutation analysis was could be performed with as few as 25 tumor cells. These results demonstrate that as few as 25 tumor cells, either in groups or as individual cells dispersed within a cytology smear slide specimens, are sufficient to detect EGFR mutations.

\section{EGFR gene sequencing and mutation status}

A total of 17 samples were tested for EGFR mutation status by the pyrosequencing. Seventeen cases showed EGFR

Table 1. Assay for estimating the minimal number of cells required for EGFR mutation analysis by the pyrosequencing 76 cytology specimens of lung adenocarcinomas from 76 patients

\begin{tabular}{|c|c|c|}
\hline Source of Samples & Number of cells & Mutation detected \\
\hline \multirow[t]{5}{*}{ Bronchial washing $(n=37)$} & 25 & Exon 19 deletion(2), c.2573T>G(1), Wild type(2) \\
\hline & 50 & Exon 19 deletion(1), c.2573T>G(1), Wild type(2) \\
\hline & 100 & c. $2573 \mathrm{~T}>\mathrm{G}(4)$, Wild type(6) \\
\hline & 200 & Exon 19 deletion(3), c.2573T>G(2), Wild type(6) \\
\hline & 300 & Exon 19 deletion(4), c.2573T>G(1), Wild type(2) \\
\hline \multirow[t]{5}{*}{ Pleural fluid (n=39) } & 25 & Exon 19 deletion(1), c.2573T>G(1), Wild type(1) \\
\hline & 50 & c.2573T>G(2), Wild type(4) \\
\hline & 100 & $\begin{array}{l}\text { Exon } 19 \text { deletion(2), c.2573T }>\mathrm{G}(5) \text {, c. } 2369 C>\mathrm{T}(1) \text {, } \\
\text { Exon } 19 \text { deletion \& c.2369C }>\mathrm{T}(1) \text { Wild type(2) }\end{array}$ \\
\hline & 200 & Exon 19 deletion(2), c.2573T>G(2), Wild type(5) \\
\hline & 300 & c.2573T>G(2), c.2319_2320insCAC(1), Wild type(7) \\
\hline
\end{tabular}


Table 2. Comparison of EGFR mutation analysis of microdissection-assisted cytology specimens with previously performed test on surgical or cytology specimens

\begin{tabular}{|c|c|c|c|c|c|}
\hline Patient & No. of Cells & Microdissection Source & Microdissection mutation & Original source & Original mutation \\
\hline 1 & 25 & bronchial washing & c. $2573 T>$ G p.L858R & $\mathrm{BAL}(\mathrm{C})$ & c. $2573 T>G$ p.L858R \\
\hline 2 & 25 & bronchial washing & Exon 19 deletion* & Lung (SB) & Exon 19 deletion* \\
\hline 3 & 25 & bronchial washing & Exon 19 deletion* & Lung (SB) & Exon 19 deletion* \\
\hline 4 & 100 & bronchial washing & c.2573T>G p.L858R & Lung (SB) & wild type \\
\hline 5 & 100 & pleural fluid & c. $2573 \mathrm{~T}>\mathrm{G}$ p.L858R & Lung (SB) & wild type \\
\hline 6 & 150 & pleural fluid & Exon 19 deletion* & Lung (SB) & Exon 19 deletion* \\
\hline 7 & 150 & pleural fluid & Exon 19 deletion* & Lung (SB) & Exon 19 deletion* \\
\hline 8 & 150 & bronchial washing & c. $2573 T>G$ p.L858R & Lung (SB) & c. $2573 T>G$ p.L858R \\
\hline 9 & 150 & pleural fluid & c. $2573 T>G$ p.L858R & LN (SE) & wild type \\
\hline 10 & 250 & pleural fluid & c. $2573 T>G$ p.L858R & LN (SE) & c. $2573 \mathrm{~T}>\mathrm{G}$ p.L858R \\
\hline 11 & 250 & bronchial washing & Exon 19 deletion* & Lung (SB) & Exon 19 deletion* \\
\hline 12 & 250 & bronchial washing & c.2573T>G p.L858R & Lung (SB) & c. $2573 T>$ G p.L858R \\
\hline 13 & 300 & bronchial washing & Exon 19 deletion* & Lung (SB) & Exon 19 deletion* \\
\hline 14 & 300 & bronchial washing & Exon 19 deletion* & Lung (SB) & Exon 19 deletion* \\
\hline 15 & 300 & pleural fluid & c. $2573 T>G$ p.L858R & $\mathrm{PF}(\mathrm{C})$ & c. $2573 T>$ G p.L858R \\
\hline 16 & 300 & bronchial washing & Exon 19 deletion* & Lung (SB) & Exon 19 deletion* \\
\hline 17 & 300 & pleural fluid & c.2573T>G p.L858R & $\mathrm{PF}(\mathrm{C})$ & c. $2573 \mathrm{~T}>\mathrm{G}$ p.L858R \\
\hline
\end{tabular}

LN, lymph node; C, cytology specimen; SB, surgical biopsy; SE, surgical excision.

*Exon 19 deletion, include all type of c.2235_2258 in-frame deletion.

mutations, with six cases containing a point mutation c.2573T $>$ G p.L858R in exon 21 and eight cases with an in-frame deletion in exon 19. Three cases were wild type for EGFR. All 17 cases had mutation status analyses that had been previously documented on surgical biopsies, surgical excision or cytology material that were in concordance with the current results. When microdissection-assisted 17 samples were analyzed, in the previously three wild type cases, has been changed a point mutation c.2573T $>$ G p.L858R (Table 2). In cases where the tumor load is low and tumor cells are sparse and dispersed, isolating a more pure population of tumor cells can yield a more sensitive method for mutation detection.

\section{Microdissection increased sensitivity of mutation detection}

To evaluate the effectiveness of selectively using a pure population of tumor cells by microdissection, One cases (pleural fluids: cases 5) with approximately $\leq 20 \%$ tumor cells were selected for mutation analysis (Fig. 1A). We compared mutation assays following whole slide scraping of a cytology smear slide with microdissection-assisted analysis from a cytology smear slide ( $\sim 100$ cells). We failed to detect the mutation from the standard method of whole slide scraping;
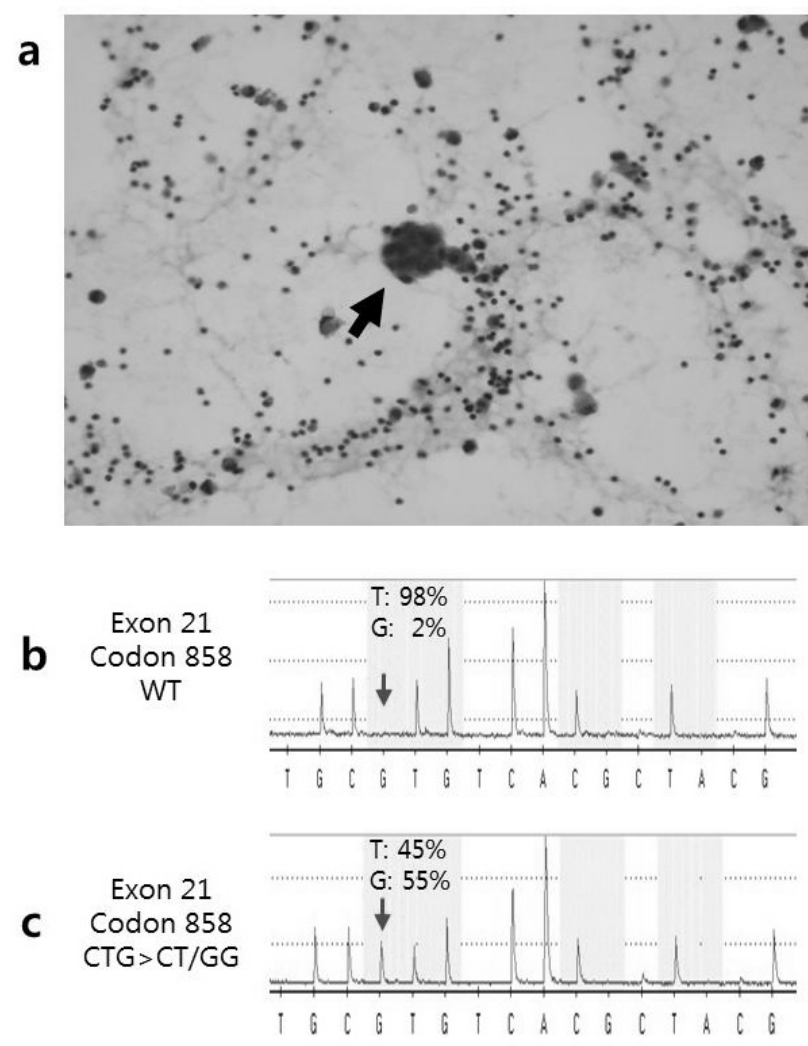

Fig. 1. Microdissection increases sensitivity of mutation detection. (a) Papanicolau-stained pleural fluid cytology slide showing tumor cells (arrow head) in a background of lymphocytes and mesothelial cells. (b) Pyrogram from EGFR mutation assay for exon 21 from a whole slide scrape of the same case showing wild type. (c) Pyrogram from EGFR mutation assay for exon 21 following microdissection showing detection of c.2573 T>G (L858R) mutation. 
however, the microdissection-assisted analysis was able to identify the appropriate mutation for all two cases (Fig. 1B and $\mathrm{C}$ ). In cases where the tumor load is low and tumor cells are sparse and dispersed, isolating a more pure population of tumor cells can yield a more sensitive method for mutation detection in comparison with standard methods.

\section{Discussion}

The diagnosis of lung cancer is often based solely on cytology specimens (Rivera et al., 2003; Travis et al., 2010). As often the number of tumor cells is limited on cytology specimens, it is critical to develop sensitive assays for mutation detection from small samples. Previous studies have shown that direct sequencing cannot consistently detect mutant DNA in specimens with $<50 \%$ tumor cells and can rarely detect mutations in specimens with $<25 \%$ tumor cells (Smouse et al., 2009). For mutation analysis, enrichment of tumor cells is important to avoid diluting tumor DNA with the non mutated DNA of benign cells, which in most cases represents the larger proportion of the cell population. Manual microdissection has been previously used on cytology specimens to extract DNA for EGFR mutation analysis (Boldrini et al., 2007). However, samples with lower numbers of tumor cells were rejected or reported as inconclusive because of technical difficulties of isolating a pure population of malignant cells.

In this study, We were validated a method for mutation analysis in archival smear cells of 76 cytology cases containing as few as 25 tumor cells using manual microdissection with a needle. Microdissection using resolution solution can be successfully used to selectively isolate tumor cells, even in cases where the stochastic distribution of tumor and benign cells precludes more traditional methods of enrichment such as scraping whole samples.

There have been arguments against using extremely small amounts of DNA for PCR-based mutational analysis as artifactual mutations have been described especially in DNA extracted from paraffin embedded tissue (Williams et al., 1999; Quach et al., 2004; Tsao et al., 2005; Marchetti et al., 2006). However, improved methods using DNA extraction solution specially adapted for microdissected specimens from archival smear cells have improved downstream analysis for samples with small amounts of DNA. DNA extraction solution method not only detected mutations consistently from 25 tumor cells (Table 1), but also detected the exact same mutation that had been previously identified in each of these patients. Three samples were detected c.2573T >G p.L858R mutation from previously wild type (Table 2).

Microdissection increased the sensitivity of mutation detection in specimens with limited number of tumor cells, and therefore could significantly increase the number of patients who can be screened for mutation. Because clinical specimens often have a limited number of cells, a reproducible and cost-effective DNA extraction method is absolutely needed. Microdissection with DNA extraction solution demonstrated the possibility of successful molecular genetic testing even with 25 tumor cells. This minimum requirement of 25 cells is overwhelmingly advantageous, as it provides the ability to apply various molecular techniques to cytological specimens.

New diagnostic modalities like ultrasound-guided trans bronchial needle aspiration are increasingly being used to stage lung cancer of lymph nodes for metastasis (Yasufuku et al., 2005). These new minimally invasive sampling procedures provide opportunities, but to fully take advantage of their promise, more sensitive analytic approaches capable of interrogating very small amounts of tissue must be developed. If cytological specimens such as bronchial wash specimens could replace lung biopsy specimens when analyzing EGFR mutation status in patients with inoperable lung cancer, it would be a powerful option, as repeated lung biopsy could be avoided in patients with poor clinical condition. In addition to the cytological specimens, histological specimens could also benefits by cells could be utilized for molecular analysis. In practice, small biopsy specimens are often not available for additional genetic testing. In that case, genetic tests can still be performed using previously stained slides.

In conclusion, our study demonstrates that microdissection-assisted EGFR mutation analysis from cytology samples provides results that match those obtained from whole cytology slide scrapes typically used for clinical molecular diagnostic testing. We have shown that EGFR 
mutation analysis can be performed consistently and reproducibly with as few as 25 tumor cells, and that tumor cell enrichment attainable through the use of microdissection allows for more sensitive mutation detection. Highly sensitive and reproducible approaches to mutation analysis, such as the method described here, should facilitate the use of cytological materials for the molecular testing that underpins the newly emerging molecular-based personalized therapies.

\section{요 약}

폐 선암의 일부에서 $E G F R$ 돌연변이 활성화의 발견은 폐 선암의 생물학적 이해와 티로신 키나아제 억제제 치료에 대한 획기적인 연 구에 중요하다. 세포 검체 검사는 폐암 진단에 중요한 역할을 하고 있으나 세포 검체로 부터 얻은 종양세포가 소량으로 돌연변이검사 및 다른 전문연구의 시행에 제한적이다. 본 연구에서는 폐선 암으 로 알려진 76명의 환자로부터 얻은 세포슬라이드에서 미세절제기 법을 통해 소량의 종양세포를 분리한 후 $E G F R$ 돌연변이 검사를 시 행하였다. 본 연구 결과는 이전 초기임상 진단의 일환으로 세포 및 조직으로 시행되었던 $E G F R$ 돌연변이 검사 결과와 비교 분석하였 다. 미세절제 기법으로 분리된 모든 종양세포는 파이로시퀀싱을 통 하여 $E G F R$ 돌연변이 분석이 가능했을 뿐만 아니라 25 개의 종양세 포에서도 $E G F R$ 돌연변이 분석이 가능했다. 또한, 돌연변이 분석에 서 미세절제기법을 통해 순수한 종양세포의 양을 증가시킨 검체에 서 돌연변이 검출 감도가 증가하였다. 따라서, 미세절제기법은 세 포 검체로 $E G F R$ 돌연변이 분석을 시행 할수 있는 폐 선암 환자의 수 를 증가시킬 뿐만 아니라 폐 선암 환자의 분자기반 맞춤치료에 세 포 검체가 용이하게 사용될 수 있다.

\section{Acknowledgements: None}

Funding: None

Conflict of interest: None

\section{References}

1. Asano H, Toyooka S, Tokumo M. Ichimura K, Aoe K, Ito S, et al. Detection of EGFR gene mutation in lung cancer by mutant enriched polymerase chain reaction assay. Clin Cancer Res. 2006,12:43-48.

2. Boldrini L, Gisfredi S, Ursino S, Camacci T, Baldini E, Melfi F, et al. Mutational analysis in cytological specimens of advanced lung adenocarcinoma: a sensitive method for molecular diagnosis. J Thorac Oncol. 2007,2:1086-1090.
3. Clark DP. Seize the opportunity: underutilization of fine-needle aspiration biopsy to inform targeted cancer therapy decisions. Cancer Cytopathol. 2009,117:289-297.

4. Eberhard DA, Johnson BE, Amler LC, Goddard AD, Heldens SL, Herbst RS, et al. Mutations in the epidermal growth factor receptor and in KRAS are predictive and prognostic indicators in patients with non-small-cell lung cancer treated with chemotherapy alone and in combination with erlotinib. J Clin Oncol. 2005,23:5900-5909.

5. El-Serag HB, Nurgalieva ZZ, Mistretta TA. Gene expression in Barrett's esophagus: laser capture versus whole tissue. Scand J Gastroenterol. 2009,44:787-795.

6. Emmert-Buck MR, Bonner RF, Smith PD, Chuaqui RF, Zhuang Z, Goldstein SR, et al. Laser capture microdissection. Science. 1996,274:998-1001.

7. Fend F, Raffeld M. Laser capture microdissection in pathology.J Clin Pathol. 2000,53:666-672.

8. Han SW, Kim TY, Hwang PG, Jeong SH, Kim JM, Choi IS, et al. Predictive and prognostic impact of epidermal growth factor receptor mutation in non-small-cell lung cancer patients treated with gefitinib. J Clin Oncol. 2005,23: 2493-2501.

9. Harrell JC, Dye WW, Harvell DM. Contaminating cells alter gene signatures in whole organ versus laser capture microdissected tumors: a comparison of experimental breast cancers and their lymph node metastases. Clin Exp Metastasis. 2008, 25:81-88.

10. Hwang TS. Molecular Biologic Techniques in Cytopathologic Diagnosis. Korean J Pathol. 2009,43:387-392.

11. Jackman DM, Miller VA, Cioffredi LA, Yeap BY, Jänne PA, Riely GJ. Impact of epidermal growth factor receptor and KRAS mutations on clinical outcomes in previously untreated non small cell lung cancer patients: results of an online tumor registry of clinical trials. Clin Cancer Res. 2009,15:5267-5273.

12. Janne PA, Borras AM, Kuang Y. A rapid and sensitive enzymatic method for epidermal growth factor receptor mutation screening. Clin Cancer Res. 2006,12:751-758.

13. Kim HJ, Oh SY, Kim WS, Kim SJ, Yoo GH, Kim WD, et al. Clinical investigation of EGFR mutation detection by pyrosequencing in lung cancer patients. Oncology letters. 2013, 5:271-276.

14. Lynch TJ, Bell DW, Sordella R, Gurubhagavatula S, Okimoto RA, Brannigan BW, et al. Activating mutations in the epidermal growth factor receptor underlying responsiveness of nonsmall-cell lung cancer to gefitinib. $N$ Engl J Med. 2004,350: 2129-2139.

15. Marchetti A, Felicioni L, Buttitta F. Assessing EGFR mutations. $N$ Engl J Med. 2006,354:526-528.

16. Mok TS, Wu YL, Thongprasert S, Yang CH, Chu DT, Saijo N, et al. Gefitinib or carboplatin-paclitaxel in pulmonary adenocarcinoma. N Engl J Med. 2009,361:947-957.

17. Oh SY, Han JY, Lee SR, Lee HT. Improved DNA Extraction Method for Molecular Diagnosis from Smaller numbers of Cells. Korean J Clin Lab Sci. 2014,46:99-105

18. Oh SY and Lee HT. Evaluation of Pyrosequencing Method for a BRAFV600E Mutation Test. Korean J Clin Lab Sci. 2015,47:1723.

19. Paez JG, Janne PA, Lee JC, Tracy S, Greulich H, Gabriel S, et al. 
EGFR mutations in lung cancer: correlation with clinical response to gefitinib therapy. Science. 2004,304: 1497-1500.

20. Pao W, Miller V, Zakowski M, Doherty J, Politi K, Sarkaria I, et al. EGF receptor gene mutations are common in lung cancers from "never smokers" and are associated with sensitivity of tumors to gefitinib and erlotinib. Proc Natl Acad Sci. 2004,101:1330613311.

21. Quach N, Goodman MF, Shibata D. In vitro mutation artifacts after formalin fixation and error prone translesion synthesis during PCR. BMC Clin Pathol. 2004,4:1.

22. Rivera MP, Detterbeck F, Mehta AC. Diagnosis of lung cancer: the guidelines. Chest. 2003,123:129S-136S.

23. Rosell R, Taron M, Reguart N. Epidermal growth factor receptor activation: how exon 19 and 21 mutations changed our understanding of the pathway. Clin Cancer Res. 2006,12:7222-7231.

24. Smith GD, Chadwick BE, Willmore-Payne C. Detection of epidermal growth factor receptor gene mutations in cytology specimens from patients with non-small cell lung cancer utilising high-resolution melting amplicon analysis. J Clin Pathol. 2008,61:487-493.

25. Smouse JH, Cibas ES, Janne PA, Joshi VA, Zou KH. EGFR muta- tions are detected comparably in cytologic and surgical pathology specimens of nonsmall cell lung cancer. Cancer Cytopathol. 2009,117:67-72.

26. Travis WD, Rekhtman N, Riley GJ. Pathologic diagnosis of advanced lung cancer based on small biopsies and cytology: a paradigm shift. J Thorac Oncol. 2010,5:411-414.

27. Tsao MS, Sakurada A, Cutz JC, Zhu CQ, Kamel-Reid S, Squire J, et al. Erlotinib in lung cancer - molecular and clinical predictors of outcome. N Engl J Med. 2005,353:133-144.

28. West H, Lilenbaum R, Harpole D, Wozniak A, Sequist L. Molecular analysis-based treatment strategies for the management of non-small cell lung cancer. J Thorac Oncol. 2009, 4:S1029-S1039.

29. Williams C, Ponten F, Moberg C, Soderkvist P, Uhlén M, Pontén $\mathrm{J}$, et al. High frequency of sequence alterations is due to formalin fixation of archival specimens. Am J Pathol. 1999,155: 1467-1471.

30. Yasufuku K, Chiyo M, Koh E, Moriya Y, Iyoda A, Sekine Y, et al. Endobronchial ultrasound guided transbronchial needle aspiration for staging of lung cancer. Lung Cancer. 2005,50:347-354. 